\title{
PENGARUH LABA AKUNTANSI DAN ARUS KAS TERHADAP RETURN SAHAM PERUSAHAAN YANG LISTING DI BEI
}

\author{
Sri Purwanti, Endang Masitoh W., dan Yuli Chomsatu \\ UNIBA Surakarta \\ Email : purwanti0312@yahoo.com
}

\begin{abstract}
This study aimed to examine the effect of accounting earnings and cash flow to stock returns companies listed on the Stock Exchange. This study used a sample of 44 companies. Samples were selected based on purposive sampling technique. Data used is secondary data. Analysis of the data using the classical assumption test and multiple linear regression analysis. Variables used in this study is the accounting profit, operating cash flow, cash flow financing, and cash flows of the investment as an independent variable. Stock return as the dependent variable. The results show that accounting earnings and cash flow simultaneously significant effect on stock returns. Accounting profit significantly influence stock returns. Operating cash flow does not have a significant effect on stock returns . Financing cash flows have a significant effect on stock returns. Investment cash flow does not have a significant effect on stock returns.
\end{abstract}

Keywords : Earnings, Cash, Stock Return

\section{PENDAHULUAN}

Pasar modal (capital market ) merupakan pasar untuk berbagai instrumen keuangan jangka panjang yang bisa diperjualbelikan, baik surat utang (obligasi), ekuiti (saham), reksa dana, instrumen derivatif maupun instrumen lainnya. Pasar modal sebagai tempat bertemunya lender dan borrower menyediakan banyak informasi yang sangat dibutuhkan oleh investor maupun kreditor. Informasi tersebut menjadi acuan bagi mereka dalam rangka pengambilan keputusan. Efisiensi pasar modal dapat dilihat dari kecepatan pasar dalam menyerap informasi baru ke dalam perubahan harga sekuritas.

Laporan keuangan merupakan salah satu sumber informasi keuangan perusahaan yang didalamnya mengandung berbagai informasi penting. Menurut PSAK nomor 1 (revisi 2013), laporan keuangan adalah suatu penyajian terstruktur dari posisi keuangan dan kinerja suatu entitas. Tujuan laporan keuangan adalah untuk memberikan informasi mengenai posisi keuangan, kinerja keuangan, dan arus kas entitas yang bermanfaat bagi sebagian besar kalangan pengguna laporan dalam pembuatan keputusan investasi. Laporan keuangan juga menunjukkan hasil pertanggungjawaban manajemen atas penggunaan sumber daya yang dipercayakan kepada mereka.

Informasi yang terdapat dalam laporan keuangan meliputi aset, liabilitas, ekuitas, pendapatan dan beban termasuk laba atau rugi. Laporan keuangan yang lengkap terdiri dari laporan posisi keuangan pada akhir periode, laporan laba rugi komprehensif selama periode, laporan perubahan ekuitas selama periode, laporan arus kas selama periode, catatan atas laporan keuangan yang berisi ringkasan, serta kebijakan akuntansi dan informasi penjelasan lainnya.

Laba merupakan salah satu elemen laporan keuangan yang memiliki kandungan informasi lebih tinggi. Laba sering dijadikan sumber untuk mengukur kinerja perusahaan. Laba merupakan kenaikan manfaat ekonomi selama satu periode akuntansi dalam bentuk pemasukan, perubahan aktiva atau penurunan kewajiban yang menyebabkan kenaikan ekuitas yang tidak berasal dari kontribusi penambahan modal. Informasi laba dapat digunakan untuk memprediksi laba di masa mendatang serta memperkirakan resiko investasi 
maupun kredit. Oleh karena itu, informasi laba sebagai indikator kinerja suatu perusahaan merupakan fokus utama dari pelaporan keuangan saat ini (Rahmawati, 2005).

Informasi penting lainnya yang diperoleh dari laporan keuangan adalah informasi arus kas. Data arus kas dianggap menyajikan informasi utama dalam mengevaluasi harga pasar surat-surat berharga (Hendriksen, 1997). Arus kas memiliki arti penting dalam mengevaluasi harga pasar saham karena menggambarkan daya beli umum dan dapat dipindahkan segera dalam perekonomian pasar kepada perorangan maupun organisasi utuk kepentingan tertentu.

Arus kas sering kali digunakan investor untuk menganalisa investasi. Data arus kas menunjukkan bagaimana kemampuan perusahaan dalam menghasilkan kas. (Wibowo, 2009) melakukan penelitian yang menguji pengaruh informasi arus kas operasi terhadap return saham dengan earning per share sebagai variabel mediasi. Hasil penelitian menunjukkan bahwa tidak ada pengaruh antara arus kas operasi terhadap return saham dengan earning per share sebagai variabel mediasi, sehingga hipotesis yang dibuat tidak mendapat dukungan empiris.

Penelitian serupa juga dilakukan oleh (Hartono, 2012) yang menguji pengaruh informasi laba dan arus kas terhadap harga saham. Hasil Penelitian menunjukkan bahwa total arus kas tidak memiliki pengaruh yang signifikan terhadap harga saham. Akan tetapi, pemisahan arus kas ke komponen arus kas operasi, arus kas pendanaan, dan arus kas investasi memiliki pengaruh yang signifikan terhadap harga saham.

Penelitian (Latief, 2014) menguji pengaruh komponen arus kas, laba akuntansi dan dividen yield terhadap return saham. Hasil dari penelitian tersebut membuktikan bahwa arus kas operasi berpengaruh positif dan signifikan terhadap return saham. Arus kas investasi berpengaruh positif dan tidak signifikan terhadap return saham. Arus kas pendanaan berpengaruh positif dan signifikan terhadap return saham Laba akuntansi berpengaruh positif dan tidak signifikan terhadap return saham. Sedangkan deviden yield berpengaruh negatif dan tidak signifikan terhadap return saham.

Penelitian ini merupakan penelitian lanjutan dari penelitian - penelitian sebelumnya. Beberapa penelitian sebelumnya menunjukkan hasil yang berbeda. Oleh karena itu, penulis tertarik untuk melakukan generalisasi terhadap penelitian sebelumnya. Berdasarkan latar belakang diatas maka penulis ingin melakukan penelitian dengan judul : "Pengaruh Laba Akuntansi Dan Arus Kas Terhadap Return Saham Perusahaan Yang Listing Di BEI."

\section{TINJAUAN PUSTAKA PENGEMBANGAN HIPOTESIS Teori Signal}

Teori signal menjelaskan mengapa perusahaan memiliki dorongan untuk memberikan informasi laporan keuangan kepada pihak eksternal. Pihak eksternal yang dimaksud diantaranya investor, kreditor, atau pengguna informasi lainnya. Perusahaan memberikan informasi laporan keuangan karean adanya asimetri informasi antara perusahaan dengan pihak eksternal. Kurangnya informasi pihak eksternal mengenai perusahaan menyebabkan mereka melindungi diri dengan memberikan harga rendah pada perusahaan yang bersangkutan. Pihak eksternal yang tidak memiliki informasi yang cukup juga akan menilai bahwa semua perusahaan memiliki nilai yang sama. Penilaian seperti ini tentunya akan merugikan bagi perusahaan yang memiliki kondisi lebih baik karena pihak eksternal akan menilai perusahaan lebih rendah dari yang seharusnya begitu pula sebaliknya. Oleh karena itu, perusahaan perlu memberikan signal kepada pihak eksternal yang dapat berupa informasi keuangan yang dapat dipercaya dan dapat mengurangi ketidakpastian mengenai prospek perusahaan di masa mendatang.

Pada penelitian ini perusahaan memberikan signal kepada pengguna laporan keuangan (investor) berupa informasi laba akuntansi dan arus kas. Informasi ini sangat penting bagi para pengguna laporan keuangan sehingga pelaporan laba rugi dan laporan arus kas diharapkan dapat menimbulkan reaksi pasar. Reaksi pasar ditunjukkan dengan adanya perubahan harga saham perusahaan tertentu yang cukup signifikan pada saat pengumuman laporan keuangan.

Angka akutansi yang dilaporkan oleh perusahaan didalam laporan keuangan dapat digunakan sebagai signal jika angka tersebut mencerminkan informasi mengenai kelengkapankelengkapan keputusan perusahaan yang tidak dapat diamati. Angka tersebut pada saat perusahaan melaporkan komponen labanya kepada 
publik maka akan menjadi sebuah berita bagus karena dianggap perusahaan memberikan informasi yang lengkap mengenai perusahaan (Meythi, 2002).

\section{Laba Akuntansi}

Laba merupakan kenaikan manfaat ekonomi selama satu periode akuntansi dalam bentuk pemasukan, perubahan aktiva atau penurunan kewajiban yang menyebabkan kenaikan ekuitas yang tidak berasal dari kontribusi penambahan modal. Laba diartikan sebagai imbalan atas upaya perusahaan dalam menghasilkan barang atau jasa sehingga laba merupakan kelebihan pendapatan diatas biaya.

Laba bersih adalah selisih positif dari seluruh pendapatan dikurangi seluruh biaya dan pajak. Laba bersih merupakan laba operasi dikurangi pajak, biaya bunga, biaya riset, dan pengembangan. Menurut (Widiastuty, 2005), laba bersih merupakan laba yang menunjukkan bagian laba yang akan ditahan di dalam perusahaan dan yang akan dibagikan sebagai deviden. Laba bersih disajikan dalam laporan rugi-laba dengan menyandingkan antara pendapatan dengan biaya (M.Mowen, 2001).

\section{Arus Kas}

Arus kas merupakan salah satu komponen laporan keuangan yang memiliki arti penting dalam penilaian harga saham perusahaan. Arus kas berisi aliran kas masuk dan kas keluar perusahaan selama periode tertentu. Informasi arus kas berguna sebagai indikator jumlah arus kas di masa mendatang, serta berguna untuk menilai kecermatan atas taksiran arus kas yang telah dibuat sebelumnya.

Arus kas sebagai salah satu komponen dalam laporan keuangan yang penting bagi para pengguna laporan keuangan diklarifikasikan menjadi tiga komponen, yaitu :

a. Arus kas operasi

Arus kas operasi merupakan jumlah arus kas yang berasal dari aktivitas operasi perusahaan. Aktivitas operasi adalah aktivitas penghasil utama pendapatan perusahaan dan aktivitas lain yang bukan merupakan aktivitas investasi dan aktivitas pendanaan. Beberapa contoh aktivitas operasi diantaranya :

1) Penerimaan kas dari pelanggan
2) Pembayaran kas kepada pemasok

3) Pembayaran kas kepada karyawan

b. Arus kas pendanaan

Arus kas yang berasal dari aktivitas pendanaan mencakup transaksi dan peristiwa yang melibatkan pos-pos kewajiban sehingga mengakibatkan perubahan dalam jumlah serta komposisi modal dan pinjaman perusahaan. Beberapa contoh arus kas pendanaan adalah sebagai berikut :

1) Pembayaran kas kepada pemegang saham untuk menebus sahamnya

2) Penerimaan kas dari emisi saham atau instrumen modal lainnya

3) Pelunasan pinjaman

c. Arus kas investasi

Aktivitas investasi adalah perolehan dan pelepasan aktiva jangka panjang serta investasi lain yang tidak termasuk setara kas. Beberapa aktivitas investasi adalah sebagai berikut :

1) Pembayaran utang untuk pembelian aktiva tetap, aktiva tidak berwujud, dan aktiva jangka panjang lainnya

2) Penerimaan kas dari penjualan tanah, bangunan, aktiva jangka panjang dan aktiva tidak berwujud lainnya

\section{Return Saham}

Saham merupakan surat berharga yang menunjukkan kepemilikan perusahaan sehingga para pemegang saham memiliki hak klaim atas deviden maupun asset perusahaan dengan prioritas setelah hak klaim pemegang saham lain dipenuhi jika terjadi likuiditas. Saham adalah surat berharga yang dikeliuarkan oleh perusahaan yang berbentuk Perseroan Terbatas (PT) dan diperdagangkan di pasar modal dan menunjukkan bahwa pemilik saham tersebut juga sebagai bagian dari pemilik perusahaan.

Investor tertarik untuk melakukan investasi dengan membeli saham perusahaan dengan harapan dapat menerima kembalian atsa investasi yang dilakukan. Hasil yang diperoleh dari investasi atau tingkat keuntungan yang diperoleh investor atas investasi yang dilakukan dinamakan return.

Return saham dibedakan menjadi dua macam yaitu return realisasi dan return ekspektasi. Return realisasi merupakan return yang sudah terjadi berdasarkan data historis. Return realisasi dapat digunakan sebagai salah satu pengukiuran kinerja perusahaan dan dapat digunakan sebagai dasar 
penentuan return ekspektasi maupun resiko di masa mendatang. Return ekspektasi merupakan return yang diharapkan oleh investor yang sifatnya belum pasti.

\section{Pengaruh Laba Akuntansi Terhadap Return Saham}

Transaksi di pasar modal terjadi karena adanya informasi yang cukup untuk pengambilan keputusan. Laba sebagai salah satu informasi yang sering dijadikan sumber pengukuran kinerja. Laba akuntansi ditentukan berdasarkan konsep akuntansi akrual. Informasi laba akuntansi dianggap relevan apabila menimbulkan reaksi pasar oleh para investor. Reaksi pasar ditunjukkan dengan adanya perubahan return saham. Semakin tinggi nilai laba akuntansi, maka akan menimbulkan reaksi positif yaitu return saham meningkat karena perusahaan dianggap mempunyai kinerja yang baik dan mampu memberikan return yang baik pula kepada investor (Dwi, 2007).

\section{Pengaruh Arus Kas Operasi Terhadap Return Saham}

Arus kas operasi menunjukkan kinerja perusahaan serta kemampuan perusahaan dalam menghasilkan laba. Jumlah arus kas dari aktivitas operasi merupakan indikator yang menetukan apakah dari kegiatan utamanya, perusahaan mampu menghasilakan arus kas yang cukup untuk melunasi pinjaman, memelihara kemampuan operasi perusahaan, dan melakukan investasi baru tanpa mengandalkan pendanaan dari luar perusahaan. Oleh karena itu, peningkatan arus kas dari aktivitas operasi akan memberikan sinyal positif bagi para investor maupun kreditor mengenai kinerja perusahaan di masa mendatang yang pada akhirnya akan mempengaruhi return saham.

\section{Pengaruh Arus Kas Pendanaan Terhadap Return Saham}

Arus kas dari aktivitas pendanaan merupakan arus kas yang berguna untuk memprediksi arus kas di masa mendatang oleh para investor. Aktivitas yang meningkatkan sumber pendanaan perusahaan seperti penerbitan obligasi maupun saham baru mampu meningkatkan struktur modal perusahaan. Hal ini akan memberikan sinyal positif bagi para investor yang akan mengakibatkan perubahan return saham.

\section{Pengaruh Arus Kas Investasi Terhadap Return Saham}

Arus kas dari aktivitas investasi merupakan arus kas yang mencerminkan penerimaan dan pengeluaran kas sehubungan dengan sumbar daya yang bertujuan untuk menghasilkan pendapatan dan arus kas masa mendatang. Adanya peningkatan arus kas dari aktivitas investasi mampu memberikan arus kas tambahan bagi perusahaan untuk meningkatkan pendapatannya. Adanya peningkatan pendapatan ini akan menarik investor maupun kreditor untuk melakukan transaksi di pasar modal. Oleh karena itu, laporan arus kas investasi dianggap mengakibatkan perubahan return saham.

Pengaruh Laba Akuntansi, Arus Kas Operasi, Arus Kas Pendanaan, dan Arus Kas Investasi Secara Simultan Terhadap Return Saham

Laba akuntansi dan arus kas merupakan informasi keuangan yang dianggap penting oleh berbagai pengguna laporan keuangan sebagai acuan pengambilan keputusan. Sama halnya dengan para investor. Mereka membutuhkan informasi - informasi tersebut untuk membantu mereka dalam pengambilan keputuan invests.

Secara teori, kenaikan laba akuntansi pada suatu perusahaan akan menarik investor untuk berinvestasi. Kenaikan laba akuntansi yang berkelanjutan diharapkan akan dapat memberikan hasil yang lebih besar bagi investor. Hal ini akan mengakibatkan perubahan harga ssham yang pada akhirnya juga mempengaruhi return saham.

Sama halnya dengan arus kas perusahaan, semakin tinggi nilai arus kas suatu perusahaan baik arus kas operasional, arus kas pendanaan, dan arus kas investasi maka kepercayaan investor akan lebih tinggi dibanding dengan perusahaan yang memiliki nilai arus kas yang rendah. Kepercayaan investor inilah yang akan menimbulkan reaksi pasar oleh para investor yaitu dengan berinvestasi pada suatu perusahaan. Reaksi ini akan menimbulkan perubahan harga saham dan tentunya akan berpengaruh pada return saham.

Secara teori, uraian tersebut menunjukkan bahwa laba akuntansi dan arus kas dianggap sebagai faktor yang mempengaruhi return saham perusahaan. Hal ini perlu diuji seberapa besar pengaruh keduanya secara simultan terhadap return saham. 


\section{Kerangka Pemikiran}

Variabel Independen (x)

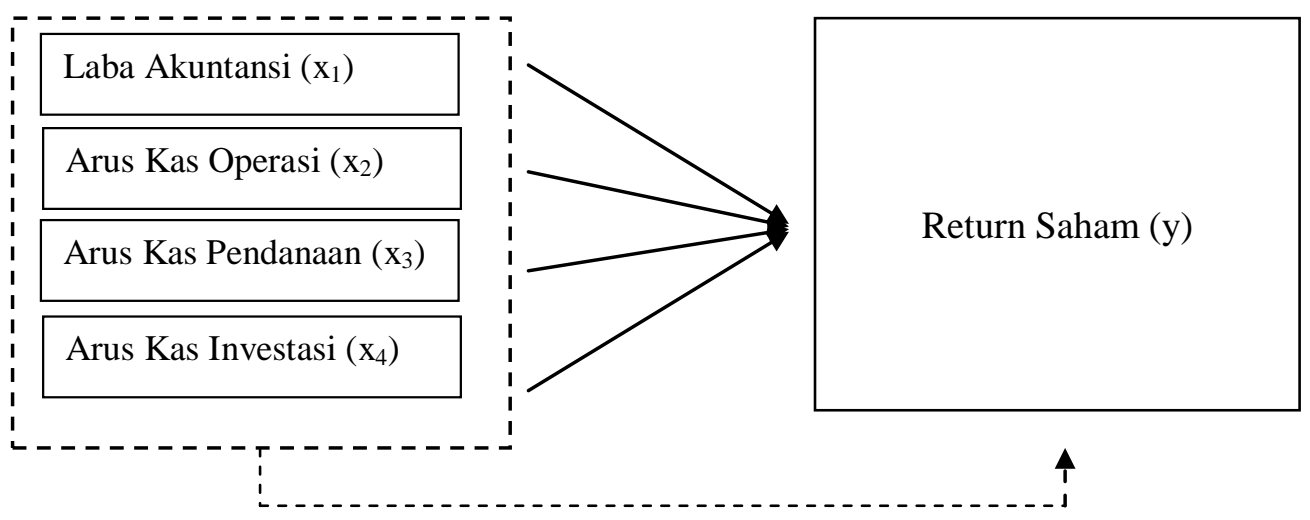

Gambar 2.1 Kerangka Pemikiran

\section{METODE PENELITIAN}

\section{Variabel dan pengukurannya}

\section{Laba Akuntansi (x1)}

Laba yang digunakan dalam penelitian ini adalah laba bersih setelah pajak yang dibandingkan dengan laba bersih setelah pajak periode sebelum pengamatan. Perubahan laba bersih dihitung dengan skala rasio. Rasio perubahan laba bersih diperoleh dari perhitungan selisih laba bersih setelah pajak periode pengamatan $(\mathrm{t})$ dikurangi laba bersih setelah pajak periode sebelum pengamatan $(\mathrm{t}-$ 1) dibagi dengan total aset periode sebelum pengamatan ( $\mathrm{t}-1)$. Alasan menggunakan deflator total aset periode sebelum pengamatan adalah untuk menghindari nilai bias jika menggunakan laba akuntansi periode sebelumnya yang bernilai negatif. Berikut adalah rumus perhitungan perubahan laba akuntansi :

$$
\Delta \mathrm{EAT}=\left(\mathrm{EAT}_{\mathrm{t}}-\mathrm{EAT}_{\mathrm{t}-1}\right) / \mathrm{TA}_{\mathrm{t}-1}
$$

Keterangan :
$\triangle$ EAT $\quad=$ Perubahan laba bersih
EAT $_{\mathrm{t}}=$ Laba bersih periode $\mathrm{t}$
EAT $_{\mathrm{t}-1} \quad=$ Laba bersih periode $\mathrm{t}-1$
$\mathrm{TA}_{\mathrm{t}-1} \quad=$ Total asset periode $\mathrm{t}-1$

\section{Arus Kas Operasi (x2)}

Arus kas operasi yang digunakan dalam penelitian ini adalah perubahan arus kas operasi periode pengamatan dengan arus kas operasiperiode sebelum pengamatan (t-1). Perubahan arus kas operasi dihitung dari selisih arus kas operasi periode pengamatan (t) dengan arus kas operasi periode sebelum pengamatan ( $\mathrm{t}-1)$ dibagi dengan total asset periode sebelum pengamatan ( $\mathrm{t}-1)$. Rumus untuk menghitung perubahan arus kas operasi adalah sebagai berikut :

$$
\Delta \mathrm{AKO}=\left(\mathrm{AKO}_{\mathrm{t}}-\mathrm{AKO}_{\mathrm{t}-1}\right) / \mathrm{TA}_{\mathrm{t}-1}
$$

Keterangan :

$\triangle \mathrm{AKO}=$ Perubahan arus kas operasi

$\mathrm{AKO}_{\mathrm{t}}=$ Arus kas operasi periode $\mathrm{t}$

$\mathrm{AKO}_{\mathrm{t}-1}=$ Arus kas operasi periode $\mathrm{t}-1$

$\mathrm{TA}_{\mathrm{t}-1}=$ Total asset periode $\mathrm{t}-1$

\section{Arus Kas Pendanaan (x3)}

Arus kas pendanaan yang digunakan dalam penelitian ini adalah perubahan arus kas pendanaan periode pengamatan dengan arus kas pendanaan periode sebelum pengamatan (t-1). Perubahan arus kas pendanaan dihitung dari selisih arus kas 
pendanaan periode pengamatan $(\mathrm{t})$ dengan arus kas pendanaan periode sebelum pengamatan ( $\mathrm{t}-1)$ dibagi dengan total asset periode sebelum pengamatan $(\mathrm{t}-1)$. Rumus untuk menghitung perubahan arus kas pendanaan adalah sebagai berikut :

$$
\Delta \mathrm{AKP}=\left(\mathrm{AKP}_{\mathrm{t}}-\mathrm{AKP}_{\mathrm{t}-1}\right) / \mathrm{TA}_{\mathrm{t}-1}
$$

Keterangan :

$\triangle \mathrm{AKP}=$ Perubahan arus kas pendanaan

$\mathrm{AKP}_{\mathrm{t}}=$ Arus kas pendanaan periode $\mathrm{t}$

$\mathrm{AKP}_{\mathrm{t}-1}=$ Arus kas pendanaan period $\mathrm{t}-1$

$\mathrm{TA}_{\mathrm{t}-1}=$ Total asset periode $\mathrm{t}-1$

\section{Arus Kas Investasi (x4)}

Arus kas investasi yang digunakan dalam penelitian ini adalah perubahan arus kas investasi periode pengamatan dengan arus kas investasi periode sebelum pengamatan ( $\mathrm{t}-1)$. Perubahan arus kas investasi dihitung dari selisih arus kas investasi periode pengamatan (t) dengan arus kas investasi periode sebelum pengamatan ( $\mathrm{t}-1)$ dibagi dengan total asset periode sebelum pengamatan $(\mathrm{t}-1)$. Rumus untuk menghitung perubahan arus kas investasi adalah sebagai berikut :

$$
\Delta \mathrm{AKI}=\left(\mathrm{AKI}_{\mathrm{t}}-\mathrm{AKI}_{\mathrm{t}-1}\right) / \mathrm{TA}_{\mathrm{t}-1}
$$

Keterangan :

$\triangle \mathrm{AKI}=$ Perubahan arus kas investasi

$\mathrm{AKI}_{\mathrm{t}}=$ Arus kas investasi periode $\mathrm{t}$

$\mathrm{AKI}_{\mathrm{t}-1}=$ Arus kas investasi period $\mathrm{t}-1$

$\mathrm{TA}_{\mathrm{t}-1}=$ Total asset periode $\mathrm{t}-1$

\section{Variabel Dependen}

\section{Return Saham (y)}

Variabel dependen dalam penelitian ini berupa return saham. Return yang digunakan adalah return realisasi atau actual return. Return realisasi adalah selisih antara harga saham saait ini dengan harga saham pada periode sebelumnya dibagi dengan harga saham periode sebelumnya. Rumus untuk menghitung return realisasi adalah sebagai berikut :

$$
\mathrm{R}_{\mathrm{it}}=\frac{\mathrm{P}_{\mathrm{it}}-\mathrm{P}_{\mathrm{it}-1}}{\mathrm{P}_{\mathrm{it}-1}}
$$

Keterangan :

$\mathrm{R}_{\mathrm{it}}=$ return realisasi saham i periode $\mathrm{ke}-\mathrm{t}$

$\mathrm{P}_{\text {it }}=$ closing price saham i periode $\mathrm{ke}-\mathrm{t}$

$\mathrm{P}_{\mathrm{it}-1}=$ closing price saham $\mathrm{i}$ periode ke $\mathrm{t}-1$

\section{Sumber data}

Data yang digunakan dalam penelitian ini merupakan data sekunder. Data sekunder merupakan data primer yang diolah lebih lanjut dan disajikan baik oleh pengumpul data primer atau pihak lain misalnya dalam bentuk tabel-tabel atau diagram-diagram (Umar, 1997). Data yang digunakan diantaranya :

a. Perusahaan yang terdaftar di Bursa Efek Indonesia tahun 2014. Data ini diperoleh dari website Bursa Efek Indonesia di www.idx.co.id

b. Data laporan keuangan publikasian tahunan (annual report) yang berupa neraca, laporan laba rugi, dan laporan arus kas tahun 2014. Data ini diperoleh dari website Bursa Efek Indonesia di www.idx.co.id

c. Data harga saham penutupan (closing price) yang diperoleh dari website www.yahoofinance.com

\section{Populasi dan Sampel}

Populasi yang digunakan dalam penelitian ini adalah perusahaan yang listing di BEI. Sampel diambil dengan metode purposive sampling dengan kriteria sebagai berikut :

a. Perusahaan tergabung dalam indeks LQ45 periode Agustus 2014 - Januari 2015

b. Perusahaan menerbitkan laporan keuangan tahunan selama periode penelitian. Laporan keuangan yang dimaksud adalah laporan keuangan tahunan per 31 Desember karena laporan keuangan tersebut telah diaudit sehingga lebih akurat dan dapat dipercaya.

\section{Metode Analisis Data}

Pengujian hipotesis dilakukan dengan uji regresi linier berganda. Analisis data dilakukan dengan alat bantu statistik SPSS vesi 17. Persamaan regresinya adalah sebagai berikut :

$\mathrm{Y}=\alpha+\beta_{1} \mathrm{X}_{1}+\beta 2 \mathrm{X}_{2}+\beta_{3} \mathrm{X}_{3}+\beta_{4} \mathrm{X}_{4}+\varepsilon$

Keterangan :

$\mathrm{Y} \quad=$ return saham

$\alpha \quad=$ konstanta

$\beta_{1} \beta_{4}=$ koefisien regresi

$\mathrm{X}_{1} \quad=$ laba bersih 
$\mathrm{X}_{2} \quad=$ arus kas operasi

$\mathrm{X}_{3} \quad=$ arus kas pendanaan

$\mathrm{X}_{4} \quad=$ arus kas investasi

$\varepsilon \quad=$ error

\section{Uji t}

Uji t dilakukan untuk menguji apakah masingmasing variabel independen secara parsial memiliki pengaruh terhadap variabel dependennya.

\section{Uji F}

Uji F dilakukan untuk menguji apakah secara simultan keseluruhan variabel independen memiliki pengaruh terhadap variabel dependennya.

\section{Uji koefisien determinasi}

Uji koefisien determinasi dilakukan untuk mengetahui prosentase nilai $\mathrm{Y}$ yang dapat dijelaskan oleh garis regresi. Prosentase return saham yang dipengaruhi oleh laba akuntansi, arus kas operasi, arus kas pendanaan, dan arus kas investasi.

\section{Hasil Penelitian Dan Pembahasan \\ 1. Uji Asumsi Klasik \\ a. Uji Normalitas}

Uji normalitas dilakukan untuk mengetahui apakah variabel yang digunakan dalam model regresi memiliki distribusi normal. Pengujian menggunakan signifikansi 0,05. Apabila nilai signifikansi lebih

besar dari 0,05 maka data terdistribusi normal. Berdasarkan pengujian diperoleh nilai signifikansi > 0,05 sehingga dapat disimpulkan bahw variabel yang digunakan memiliki distribusi normal.

\section{b. Uji Multikolinieritas}

Uji multikolinieritas dilakukan untuk mengetahui ada tidaknya satu atau lebih variabel independen mempunyai hubungan dengan variabel independen lainnya. Hasil pengujian menunjukkan nilai VIF semua variabel lebih kecil dari 10 dan nilai Tolerance lebih besar dari 0,10 . Hal ini menunjukkan bahwa tidak terdapat gejala multikolinieritas.

\section{c. Uji Autokorelasi}

Uji autokorelasi dilakukan untuk menguji apakah dalam model regresi linier terdapat korelasi antara kesalahan pengganggu pada periode $t$ dengan kesalahan pada periode $t-1$. Hasil penelitian menunjukkan nilai $\mathrm{dw}$ sebesar 1,555, sehingga dapat disipulkasn bahwa tidak terjadi autokorelasi.

\section{d. Uji heteroskedstisitas}

Uji heteroskedastisitas dilakukan untuk menguji apakah dalam model regresi terjadi atau terdapat ketidaksamaan varian dari residual dari pengamatan satu ke pengamatan yang lain. Hasil uji yang dilakukan dengan melihat grafik scatterplot menunjukkan bahwa tidak terdapat pola yang jelas, sehingga dapat disimpulkan bahwa model regresi bebas dari heteroskedastisitas.

\section{Uji Hipotesis}

\section{a. Regresi linier berganda}

Analisis regresi linier berganda yang dilakukan melalui olah data statistik diperoleh persamaan sebagai berikut :

$$
\begin{aligned}
& Y=0+0.172(\mathrm{X} 1)-0.029(\mathrm{X} 2)+ \\
& 0.048(\mathrm{X} 3)-0.035(\mathrm{X} 4)+\varepsilon
\end{aligned}
$$

\section{b. Uji hipotesis pengaruh laba akuntansi terhadap return saham}

Berdasarkan hasil olah data statistik diketahui bahwa nilai $\mathrm{t}$ hitung sebesar 2,892 dan > t tabel yaitu -2,023 dengan nilai signifikansi 0,006 . Hal ini menunjukkan bahwa variabel laba akuntansi berpengaruh signifikan terhadap return saham. Hasil penelitian ini sejalan dengan penelitian (Utomo, 2011) dan penelitian (Hartono, 2012) yang menunjukkan hasil bahwa laba akuntansi berpengaruh signifikan terhadap return saham.

Laba akuntansi berpengaruh signifikan terhadap return saham karena bagian laba yang diperoleh perusahaan dari kegiatan operasional pada akhirnya akan dibagikan kepada para pemegang saham 
sebagai imbalan atas investasinya terhadap perusahaan yang disebut dengan deviden. Perusahaan yang menghasilkan laba semakin besar maka perusahaan akan mampu membagikan deviden yang lebih besar pula kepada para pemegang saham. Peningkatan deviden yang diterima oleh pemegang saham ini akan mengakibatkan peningkatan return yang diterima oleh pemegang saham.

Hasil penelitian ini tidak konsisten dengan penelitian yang dilakukan oleh (Adiliawan, 2010) yang menunjukkan hasil bahwa laba akuntansi tidak berpengaruh pada harga saham sehingga juga tidak berpengaruh terhadap return saham. Hal ini dikarenakan pengukuran laba akuntansi yang digunakan adalah laba kotor sehingga masih menimbulkan pertanyaan bagi para investor karena didalamnya masih terdapat biaya-biaya maupun pajak yang belum diperhitungkan. Hal ini akan menimbulkan keragu-raguan bagi investor untuk berinvestasi sehingga angka laba kotor tidak menimbulkan reaksi oleh para investor.

\section{c. Uji hipotesis pengaruh arus kas operasi terhadap return saham}

Berdasarkan hasil olah data statistik diketahu bahwa nilai t hitung sebesar 0,998 dan nilai signifikansi 0,324 . Hal ini menunjukkan bahwa variabel arus kas operasi tidak berpengaruh signifikan terhadap return saham. Hasil penelitian ini konsisten dengan penelitian (Utomo, 2011) dan (Hartono, 2012) yang menunjukkan bahwa arus kas operasi tidak berpengaruh signifikan terhadap return saham.

Laba dan arus kas merupakan bagian dari laporan keuangan yang dibutuhkan investor sebagai acuan dalam mengambil keputusan investasi. Akan tetapi hasil penelitian ini menunjukkan bahwa arus kas operasi tidak berpengaruh signifikan terhadap return saham. Hal ini dimungkinkan karena investor tidak melihat dan tidak menggunakan informasi arus kas operasi sebagai bahan pertimbangan dalam pengambilan keputusan investasi karena kadang kala informasi laba akuntansi dan arus kas operasi menunjukkan informasi yang bertentangan, yaitu kenaikan laba dapat diikuti dengan penurunan arus kas operasi. Sehingga investor lebih memilih untuk menggunakan informasi laba akuntansi dibandingkan arus kas operasi.

Hasil penelitian ini tidak sejalan dengan penelitian yang dilakukan oleh (Latief, 2014) yang menunjukkan hasil bahwa arus kas operasi berpengaruh terhadap return saham. Secara teori, semakin tinggi arus kas operasi perusahaan maka semakin tinggi kepercayaan investor terhadap perusahaan karena perusahaan dianggap mampu menghasilkan arus kas masuk yang baik untuk kegiatan operasionalnya. Hal ini pada akhirnya akan meningkatkan return sahamnya.

\section{d. Uji hipotesis pengaruh arus kas pendanaan terhadap return saham}

Berdasarkan hasil olah data statistik diperoleh nilai t hitung sebesar 2,864 dan nilai signifikansi 0,007 , sehingga dapat disimpulkan bahwa variabel arus kas pendanaan berpengaruh signifikan terhadap return saham. Hasil penelitian ini konsisten dengan penelitian (Latief, 2014) yang juga menunjukkan hasil bahwa arus kas pendanaan berpengaruh posirif dan signifikan terhadap return saham.

Arus kas pendanaan merupakan arus kas yang berasal dari transaksi dan peristiwa yang melibatkan pos-pos kewajiban yang mempengaruhi komposisi modal dan pinjaman perusahaan. Secara teori, semakin tinggi arus kas pendanaan perusahaan maka semakin tinggi kepercayaan investor. Hal ini dikarenakan penerimaan dari penerbitan saham maupun instrumen modal lainnya akan menambah komposisi modal perusahaan sehingga modal akan bertambah. Selanjutnya, semakin besar modal perusahaan maka dilihat dari segi keuangan akan semakin mudah bagi perusahaan untuk mengembangkan usahanya. 
Hasil penelitian ini bertentangan dengan hasil penelitian yang dilakukan oleh (Hartono, 2012) yang menunjukkan hasil bahwa arus kas pendanaan tidak berpengaruh signifikan terhadap return saham. Hal ini karena semakin besar arus masuk pendanaan dari penerbitan saham maupun instrumen modal lainnya maka akan semakin besar pula kewajiban dan beban bunga yang harus dibayarkan kepada pihak eksternal yang nantinya akan mengurangi jumlah deviden yang akan diperoleh investor. Selain itu, arus kas masuk dari aktivitas pendanaan seperti penerbitan saham dan lainnya mencerminkan ketidakberhasilan manajemen dalam memenuhi kas untuk operasional perusahaan. Hal inilah yang mungkin menjadi alasan investor untuk tidak menggunakan informasi arus kas pendanaan.

\section{e. Uji hipotesis pengaruh arus kas investasi terhadap return saham}

Berdasarkan hasil olah data statistik diperoleh nilai $t$ hitung sebesar $-1,778$ dan nilai signifikansi 0,083 , sehingga dapat disimpulkan bahwa arus kas investasi tidak berpengaruh signifikan terhadap return saham. Hal ini sejalan dengan penelitian (Hartono, 2012) yang menunjukkan hasil bahwa arus kas investasi tidak berpengaruh signifikan terhadap return saham.

Arus kas investasi menyangkut perolehan dan pelepasan aktiva jangka panjang. Investor dalam hal ini tidak melihat informasi arus kas investasi sebagai dasar pengambilan keputusan investasinya. Hal ini dikarenakan perolehan maupun pelepasan aktiva jangka panjang dianggap tidak berdampak signifikan pada harga saham maupun return saham. Perolehan maupun pelepasan aktiva jangka panjang ini bersifat tidak rutin, sehingga tidak terlalu berdampak pada pendapatan perusahaan yang pada akhirnya tidak berdampak pula pada return yang akan diperoleh investor. Oleh karena itu, investor tidak bereaksi terhadap informasi arus kas investasi.
Hasil penelitian ini tidak konsisten dengan penelitian (Latief, 2014) yang menunjukkan bahwa arus kas investasi berpengaruh positif terhadap return saham meskipun tidak signifikan. Semakin banyak investasi yang dilakukan oleh perusahaan maka semakin besar sumber daya yang dimiliki perusahaan untuk menghasilkan pendapatan di masa mendatang. Akan tetapi pengaruh arus kas investasi tidak signifikan karena kadang kala investor beranggapan bahwa arus kas investasi tidak memiliki dampak signifikan terhadap harga saham maupun return saham melihat bahwa arus kas investasi berhubungan dengan perolehan dan pelepasan aktiva jangka panjang yang hanya bersifat insidentil atau tidak mutlak mempengaruhi pendapatan rutin perusahaan.

\section{f. Uji F}

Berdasarkan hasil olah data statistik diperoleh nilai $\mathrm{F}$ hitung sebesar 4,008, yaitu > dari nilai $F$ tabel 2,612. Nilai signifikansi diperoleh $0,008(<0,05)$ sehingga dapat disimpulkan bahwa secara simultan variabel laba akuntansi, arus kas operasi, arus kas pendanaan, dan arus kas investasi berpengaruh signifikan terhadap return saham.

Hasil Penelitian ini sejalan dengan hasil penelitian (Adiliawan, 2010) dan (Hartono, 2012) yang menunjukkan hasil bahwa laba dan arus kas secara simultan berpengaruh signifikan terhadap return saham. Hal ini menunjukkan bahwa investor menggunakan informasi informasi dalam laporan keuangan untuk pengambilan keputusan investasinya. Oleh karena itu informasi laporan keuangan tersebut menimbulkan reaksi pasar oleh para investor.

\section{Uji koefisien determinasi}

Berdasarkan hasil olah data statistik diketahui nilai Adjusted $R$ Square sebesar 0,219 atau 21,9 \%. Angka tersebut memberikan arti bahwa return saham dipengaruhi oleh laba bersih, arus kas operasi, 
arus kas pendanaan, dan arus kas investasi sebesar $21,9 \%$, sedangkan sisanya $78,1 \%$ dipengaruhi oleh variabel lain yang tidak diteliti.

Penelitian (Sari, 2014) menguji pengaruh kebijakan deviden, debt to equity ratio dan price earning ratio. Penelitian tersebut mengambil sampel perusahaan yang tergabung dalam indeks LQ45 periode 20112013. Pengujian hipotesis dilakukan dengan analisis regresi berganda. Hasil penelitian menunjukkan bahwa kebijakan deviden, debt to equity ratio dan price earning ratio berpengaruh secara simultan dan parsial terhadap return saham.

Berdasarkan penelitian tersebut maka terdapat variabel lain yang mempengaruhi return saham perusahaan yaitu kebijakan deviden, debt to equity ratio dan price earning ratio.

\section{PENUTUP}

\section{Kesimpulan}

Berdasarkan hasil penelitian tersebut dapat disimpulkan bahwa :

a. Laba akuntansi berpengaruh signifikan terhadap return saham perusahaan.

b. Arus kas operasi tidak berpengaruh signifikan terhadap return saham perusahaan

c. Arus kas pendanaan berpengaruh signifikan terhadap return saham perusahaan

d. Arus kas investasi tidak berpengaruh signifikan terhadap return saham perusahaan

e. Laba akuntansi, arus kas operasi, arus kas pendanaan, dan arus kas investasi secara simultan berpengaruh signifikan terhadap return saham perusahaan.

\section{Keterbatasan Penelitian}

Penelitian ini memiliki keterbatasan diantaranya adalah :

a. Jumlah sampel relatif sedikit hanya 44 perusahaan sehingga hasil penelitian belum mewakili seluruh perusahaan yang terdaftar di Bursa Efek Indonesia

b. Jumlah tahun pengamatan hanya satu tahun sehingga informasi laba akuntansi dan arus kas menjadi kurang relevan dalam mempengaruhi return saham

c. Nilai koefisien determinasi sangat kecil sehingga prosentase pengaruh variabel independen terhadap variabel dependen relatif kecil.

\section{Saran}

Saran untuk penelitian selanjutnya agar memperoleh hasil yang lebih baik adalah :

a. Jumlah sampel diperbanyak dengan harapan semakin banyak sampel yang digunakan akan memberikan hasil yang lebih baik

b. Jumlah tahun pengamatan diperpanjang dengan harapan semakin banyak periode pengamatan akan memberikan hasil yang lebih baik

c. Jumlah variabel independen dapat ditambah dengan rasio keuangan diantaranya debt to equity ratio dan price earning ratio.

\section{DAFTAR PUSTAKA}

Dwi, A. d. (2007). Analisis Terhadap Relevansi Nilai Laba, Arus Kas Operasi, Dan Nilai Buku Ekuitas pada Periode di Sekitar Krisis Keuangan pada Perusahaan Manufaktur di BEJ. Proceeding Seminar Nasional Inovasi Menghadapi Perubahan Lingkungan Bisnis. Jakarta: Universitas Trisakti.

Hartono, S. d. (2012). Pengaruh Informasi Laba Dan Arus Kas Terhadap Harga Saham. Jurnal Ilmiah Akuntansi No.7 .

Hendriksen, E. (1997). Accounting Theory, 4th edition. Jakarta: Erlangga.

Ikatan Akuntan Indonesia. (2013). Standar Akuntansi Keuangan. Jakarta Salemba Empat.

Latief, W. F. (2014). Pengaruh Komponen Arus Kas, Laba Akuntansi dan Dividend Yield Terhadap Return Saham. Semarang: Universitas Diponegoro. 
M.Mowen, D. H. (2001). Manajemen Bisnis Akuntansi dan Pengendalian. Jakarta: Salemba Empat.

Meythi. (2002). Pengaruh Arus Kas Operasi Terhadap Harga Saham Dengan Persistensi Laba Sebagai Variabel Intervening. Bandung: Universitas Kristen Maranatha.

Rahmawati. (2005). Relevansi Nilai Earning Dengan Pendekatan Terintegrasi : Hubungan Nonlinier. Jurnal Akuntansi \& Auditing Vol. 9.

Sari, L. P. (2014). Pengaruh Kebijakan Deviden, Debt To Equity Ratio, Dan Price Earning Ratio Terhadap Return Saham. Jurnal Akuntansi, 803.

Umar, H. (1997). Riset Akuntansi. Edisi I. Jakarta: Gramedia.

Wibowo, H. S. (2009). Pengaruh Informasi Arus Kas Operasi Terhadap Return Saham Dengan Earning Per Share Sebagai Variabel Mediasi. 2009: Universitas Sebelas Maret.

Widiastuty, R. F. (2005). Tiga Angka Laba Akuntansi : Mana Yang Lebih Bermakna Bagi Investor? Symposium Nasional Akuntansi VIII , 159-171. 